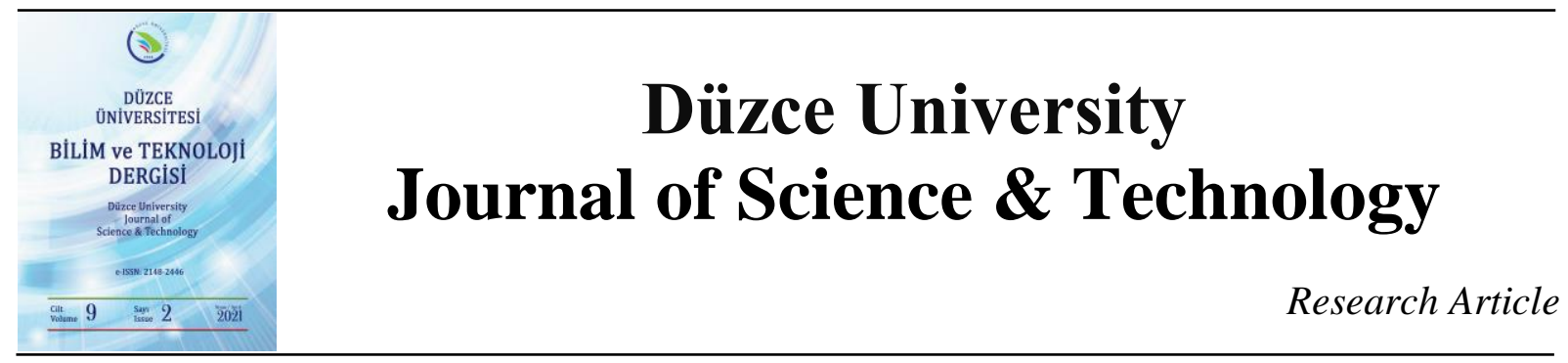

\title{
Recovery of Iron from High-Iron Hot Rolled Mill Scales by Direct Reduction Technique
}

\author{
Engin ÇEVIK ${ }^{\text {a }}$ \\ ${ }^{a}$ Department of Metallurgy And Materlals Engıneerıng, Engineering Faculty, Karabük University, Karabük, \\ TURKEY \\ * Corresponding author's e-mail address: engincevik@karabuk.edu.tr
} DOI: 10.29130/dubited.841486

\begin{abstract}
In this study, the integrated iron and steel plant mill scales were prepared to concentrate in different ratios by blending with hematite character ore. Carboxymethyl cellulose (CMC) was used as a binder and coke will be used as a reductant. The calcite was added in such a way that the basicity ratio is 0.7 . The pelletizing machine was pellet the blends containing the mill scales at different ratios and then drying at a temperature of $150{ }^{\circ} \mathrm{C} .28 \mathrm{~kg} / \mathrm{pellet}$ compressive strength was obtained in the pellets prepared from $100 \%$ mill scales. As the amount of ore increased to $75 \%, 45 \mathrm{~kg} /$ pellet was reached with a $50 \%$ increase in compressive strength. After compression tests, dried pellets were subjected to reduction at 3 different temperatures $\left(1200,1300\right.$, and $\left.1400{ }^{\circ} \mathrm{C}\right)$, and their reduction degrees were calculated based on oxygen loss. The highest reduction degree $(82 \%)$ was obtained at $1400{ }^{\circ} \mathrm{C}$ from the completely prepared with mill scales.
\end{abstract}

Keywords: Mill Scales, Direct reduction, Hematite

\section{Doğrudan İndirgeme Tekniğiyle Yüksek Demirli Sicak Haddehane Tufalinden Demirin Geri Kazanımı}

\begin{abstract}
ÖZET
$\mathrm{Bu}$ çalışmada, hematit karakterli demir cevheri ile entegre demir çelik fabrikası haddehane tufali farklı oranlarda harmanlanarak hazırlanmıştır. Bağlayııı olarak CMC ve indirgeyici olarak ise kok kullanılmıştır. Baziklik oranı 0.7 olacak şekilde kalsit ilave edilmiştir. Peletleme makinesi ile farklı oranlarda haddehane tufali içeren karışımlar pelet haline getirilmiş ve ardından $150^{\circ} \mathrm{C}^{\prime}$ de kurutulmuştur. $\% 100$ haddehane tufalinden hazırlanan peletlerde $28 \mathrm{~kg} /$ pelet basma dayanımı elde edilmiştir. Cevher miktarı arttıkça basma dayanımında \% 50 artışla $45 \mathrm{~kg} /$ pelet'e ulaşılmıştır. Basma testlerinden sonra, kurutulmuş peletler 3 farklı sıcaklıkta $\left(1200,1300\right.$ ve $\left.1400{ }^{\circ} \mathrm{C}\right)$ indirgenmeye tabi tutulmuş ve oksijen kaybına göre indirgenme dereceleri hesaplanmıştır. En yüksek indirgenme derecesine (\% 82) $1400{ }^{\circ} \mathrm{C}$ 'de tamamen haddehane tufali ile hazırlanan peletlerde ulaşılmıştır.
\end{abstract}

Anahtar Kelimeler: Haddehane tufali, Doğrudan indirgenme, Hematit 


\section{INTRODUCTION}

Raw steel production assessed as the development indicator of the countries has started to be conducted at great dimensions together with the industrial revolution. According to Brussels centered World Steel Association (Worldsteel) 2018 raw steel production data, global raw steel production was realized as 1 billion 808,6 million tons by increasing 4,6\% when compared to the previous year in 2018. All these developments bring together various environmental problems. When today's iron and steel production technologies are taken into consideration; a solid waste amount of $400 \mathrm{~kg}$ per ton of steel occurs. Almost $80 \%$ of these occurring wastes consist of slags and these are used as raw materials in some sectors such as cement [1]. Other wastes (mill scale, blast furnace flue dust, etc.) are stored within the waste areas and cause secondary emissions within the plant.

Mill scale wastes qualified as nonhazardous are one of the important problems of the companies conducting activities in the iron and steel sector. Mill scale wastes are among the wastes with high economic value due to their high iron content. The valuable compounds within the mill scale are reused and could be gained to the economy after using the mill scale wastes again. Also; the reuse of the mill scale wastes could help the protection of nature in the production of the products whose raw material is obtained from nature. Re-use of the mill scale with a sustainable production understanding is very important both in terms of the environment and human health and gaining a waste occurring in the iron and steel sector back to the economy.

In this context, the direct reduction method comes to the forefront in the assessment of the mill scale and similar wastes. Products with high iron content produced with this method are assessed as an alternative to scrap both in their EAF and BOFs. As an alternative ironmaking route; such as FASTMET rotary hearth processes; the use of composite pellets has become a popular subject for studies conducted in recent years [2-9]. In the production of composite pellets; silica-free organic binders, such as CMC, starch, and dextrin are alternative binders to bentonite $[4,10,11]$.

Period, basicity ratio, and temperature are also very important in the failure of the provision of optimum reduction in the prepared pellets [12,13,14,1]. In the study conducted by Birol in 2007, it has been specified that the thesis of Roodsari F.M. and Conochie, D.S. as the fact that "the separation of slag and metal becomes easier as basicity ratio increases" needs optimization and the best results have been attained from the pellets with the basicity ratio of 0.70 [13]. It has also been reported by Birol that 1350 ${ }^{\circ} \mathrm{C}$ is not sufficient for reduction, the separation of the desired metal and slag could only be attained at $1400{ }^{\circ} \mathrm{C}$ and 15 minutes is sufficient for the reduction and preheating [13]. In the study conducted by Kawatra and Anameric, the reduction behavior of magnetite ore has been examined at high temperatures $\left(1450{ }^{\circ} \mathrm{C}-1475{ }^{\circ} \mathrm{C}\right)$ and the results have been compared to blast furnace pig iron. They have reached a metallization degree of $94 \%$ as a result of their study [12].

In the conducted examinations, the studies of only a few researchers have been encountered on the recycling of the mill scale. In this study; both the direct recyclability of mill scale and its joined assessibility with hematite character ore have been examined by keeping the reduction period and basicity ratio stable.

\section{EXPERIMENTAL}

The following materials were used for preparing the green pellets: mill scales, iron ore, CMC, coke coal, limestone. Mill scales, coke coal, limestone, and iron ore were ground separately in a laboratory ball mill to get the required fineness for pelletizing. The chemistry of all materials is given in Table 1 . The used mill scale has very high iron content and contains too low impurity. Hematite ore is an ore rich in iron tenor and its high $\mathrm{SiO}_{2}$ content causes gang formation in high ratios. Green pellets were prepared 
using a laboratory balling disc with a diameter of $600 \mathrm{~mm}$ and a tilting angle of $45^{\circ}$ at $30 \mathrm{rpm}$. The amount of ingredients added for preparing green pellets with varying mill scales and hematite is shown in Table 2 .

Table 1. Chemical composition of materials (a) Mill scales and hematite ore (b) Coke coal (c) Calcite used for pelletizing.

\begin{tabular}{ccc}
\hline & $\begin{array}{c}\text { Mill } \\
\text { Scale } \\
(\%)\end{array}$ & $\begin{array}{c}\text { Hematite } \\
\text { Ore } \\
(\%)\end{array}$ \\
\hline $\mathbf{F e}$ & 69.06 & 57.84 \\
\hline $\mathbf{S i O}_{2}$ & 0.01 & 12.62 \\
\hline $\mathbf{C a O}$ & 0.03 & 0.03 \\
\hline $\mathbf{A l}_{\mathbf{2}} \mathbf{O}_{3}$ & 0.07 & 0.9 \\
\hline $\mathbf{M g O}$ & 0.07 & 0.01 \\
\hline $\mathbf{M n}$ & 0.55 & 0.01 \\
\hline $\mathbf{S}$ & 0.01 & 0,24 \\
\hline $\mathbf{K} \mathbf{2}$ & 0.01 & 0.01 \\
\hline $\mathbf{N a} \mathbf{O}$ & 0.07 & 0.07 \\
\hline $\mathbf{P}$ & 0.01 & 0.1 \\
\hline $\mathbf{Z n}$ & 0.01 & 0.01 \\
\hline $\mathbf{C u}$ & 0.05 & 0.04 \\
\hline $\mathbf{A s}$ & 0.01 & 0.08 \\
\hline $\mathbf{P b}$ & 0.01 & 0.01 \\
\hline $\mathbf{T i O} \mathbf{O}_{2}$ & 0.03 & 0.51 \\
\hline
\end{tabular}

(a)

\begin{tabular}{cc}
\hline $\begin{array}{c}\text { Moisture } \\
(\%)\end{array}$ & Coke \\
\hline $\begin{array}{c}\text { Ash } \\
(\%)\end{array}$ & 14.07 \\
\hline $\begin{array}{c}\text { Volatile } \\
\text { Matter } \\
(\%)\end{array}$ & 0.59 \\
\hline $\begin{array}{c}\text { Fixed } \\
\text { Carbon } \\
(\%)\end{array}$ & 85.25 \\
\hline $\begin{array}{c}\text { Sulfur } \\
(\%)\end{array}$ & 0.57 \\
\hline $\begin{array}{c}\text { Calorie } \\
(\mathrm{kcal} / \mathrm{kg})\end{array}$ & 6789 \\
\hline
\end{tabular}

(b)

\begin{tabular}{cc}
\hline & Calcite \\
\hline $\mathrm{CaCO}_{3}$ & 99.07 \\
\hline $\mathbf{M g O}$ & 0.43 \\
\hline $\mathrm{Fe}_{2} \mathbf{O}_{3}$ & 0.03 \\
\hline $\mathrm{SiO}_{\mathbf{2}}$ & 0.02 \\
\hline $\mathrm{Al}_{2} \mathbf{O}_{3}$ & 0.03 \\
\hline $\mathrm{CO}_{2}$ & 42.4 \\
\hline $\begin{array}{c}\text { Glow } \\
\text { Loss }\end{array}$ & 43.23 \\
\hline
\end{tabular}

(c)

Table 2. Ingredients of green pellets with varying amounts of components.

\begin{tabular}{|c|c|c|c|c|c|c|c|c|c|c|c|c|}
\hline \multirow[b]{2}{*}{ Sample } & \multirow[b]{2}{*}{$\mathrm{Fe} / \mathrm{C}$} & \multicolumn{2}{|c|}{ Mill Scales } & \multicolumn{2}{|c|}{ Hematite } & \multicolumn{2}{|c|}{ Coke } & \multicolumn{2}{|c|}{$\mathrm{CaCO}_{3}$} & \multirow[b]{2}{*}{ Basicity } & \multirow[b]{2}{*}{ CMC } & \multirow{2}{*}{$\begin{array}{l}\text { Weight of } \\
\text { Blend } \\
(g)\end{array}$} \\
\hline & & $(\%)$ & $\begin{array}{l}\text { Weight } \\
(g)\end{array}$ & $(\%)$ & $\begin{array}{l}\text { Weight } \\
(g)\end{array}$ & $(\%)$ & $\begin{array}{l}\text { Weight } \\
(g)\end{array}$ & $(\%)$ & $\begin{array}{l}\text { Weight } \\
(g)\end{array}$ & & & \\
\hline S1 & 3 & 77.41 & 600 & 0 & 0 & 20.9 & 162.0 & 1.68 & 13.03 & 0,7 & 38.8 & 775.0 \\
\hline S2 & 3 & 56.84 & 450 & 18.9 & 150 & 19.64 & 155.4 & 4.56 & 36.13 & 0.7 & 39.6 & 791.6 \\
\hline S3 & 3 & 37.12 & 300 & 37.1 & 300 & 18.42 & 148.9 & 7.33 & 59.24 & 0.7 & 40.4 & 808.1 \\
\hline S4 & 3 & 18.19 & 150 & 54.6 & 450 & 17.25 & 142.3 & 9.98 & 82.34 & 0.7 & 41.2 & 824.6 \\
\hline
\end{tabular}

In the drop tests ; the produced pellets have been left to free fall on a steel plate from a height of $50 \mathrm{~cm}$ have been applied to 10 ea. samples to determine their strengths and they have been repeated until the moment of their breakage. Afterward, the pellets have been subjected to a drying process of 2 hours and after that, a compression test at a speed of $5 \mathrm{~mm} / \mathrm{min}$ has been applied to 10 ea. samples using Zwick branded $50 \mathrm{kN}$ tension/compression test device. Attention has been paid for the samples subjecting to the test to be in the same dimensions.

Reductibility experiments have been conducted in the argon gas atmosphere using a high-temperature tube furnace at three different temperatures (1200-1300-1400 ${ }^{\circ} \mathrm{C}$ ). Reduction degrees have been calculated by taking the oxygen loss as the basis and taking formula 1 into consideration. The XRD 
analyses belonging to the iron grains occurring after the reduction have been conducted with the Rigaku Ultimate IV model XRD device.

$\mathrm{R}(\%)=[($ Initial oxygen content - Final oxygen content $) /($ Total oxygen content $)] \mathrm{x} 100$ (1)

After the metallographic preparation of the reduced pellets, their microstructure analyses have been conducted by using the Zeiss Ultra Plus model SEM device. EDX analyses and mapping processes have been conducted from certain zones during the SEM analyses.

\section{RESULT AND DISCUSSION}

\section{A. PELLETIZING BEHAVIOR AND MECHANICAL PROPERTIES}

The pellets to have uniform grain dimension has a great importance in terms of being able to ensure the gas permeability during the reduction [1]. No negative result has been seen in the pelletizing behavior of the pellets prepared using the blends whose compounds are given in detail in Table 2 and pellets with convenient pelletization have been produced from all blends. The macro photos belonging to the produced pellets are given in Figure 1. As seen in the Figure, attention has been paid to the requirement that the grain dimension of the pellets to be subjected to the reduction process should be between 9-16 $\mathrm{mm}[3,14]$.

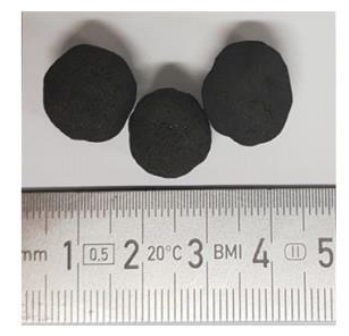

S1

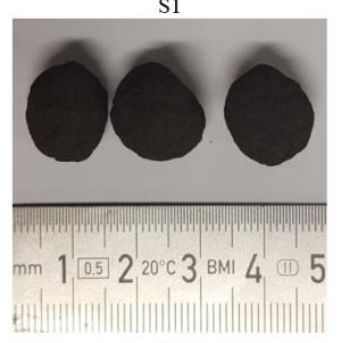

S3

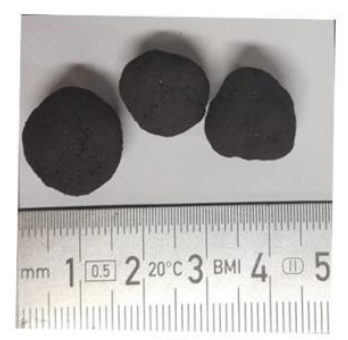

S2

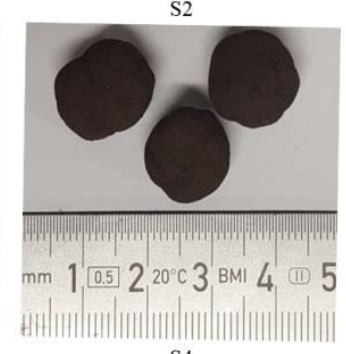

S4

Figure 1. Macro photos of green pellets.

The pellets to be used in the iron production should have a certain strength both during carrying and charge to the furnace as well as ensuring convenient grain dimension. This strength is specified as 25$30 \mathrm{~kg} / \mathrm{pellet}$ in the literature for the direct iron production furnaces [15]. The desired strengths have been reached in all produced pellets and the attained values are given as column charts in Figure 2 and Figure 3. 


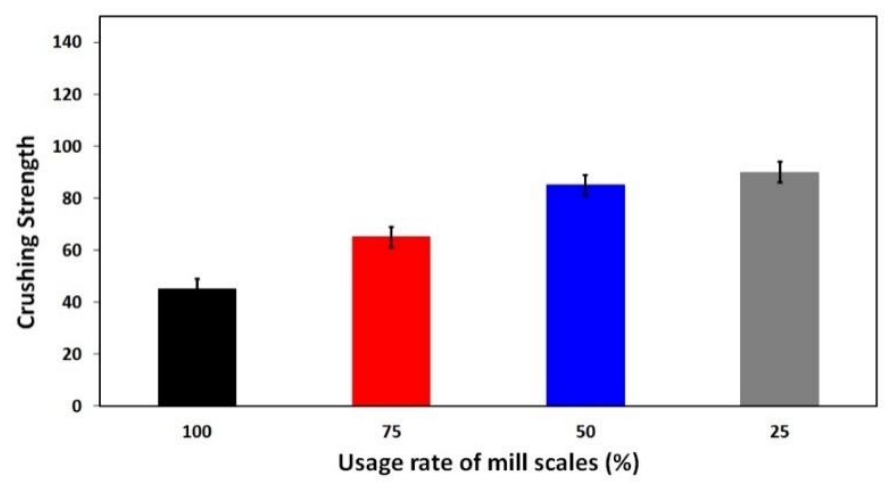

Figure 2. Crushing strength of green pellets.

$\mathrm{Fe} / \mathrm{C}$ ratio and basicity ratio are the main ones of parameters affecting reduction. Because it has been aimed to determine the impact of mill scale amount on reduction in this study, $\mathrm{Fe} / \mathrm{C}$ ratio of 3 and basicity ratio of 0,7 have been kept as stable in all compounds. While the total $\mathrm{Fe}$ amount decreases together with the increase in the added ore amount, $\mathrm{Al}_{2} \mathrm{O}_{3}$ and $\mathrm{SiO}_{2}$ amounts increase. For this reason; while the coke coal amount necessary to be added for the purpose of ensuring convenient $\mathrm{Fe} / \mathrm{C}$ ratio decreases, more $\mathrm{CaCO}_{3}$ should be added to be able to ensure the basicity ratio. It is known that coal showing hydrophobic properties negatively affects wettability.

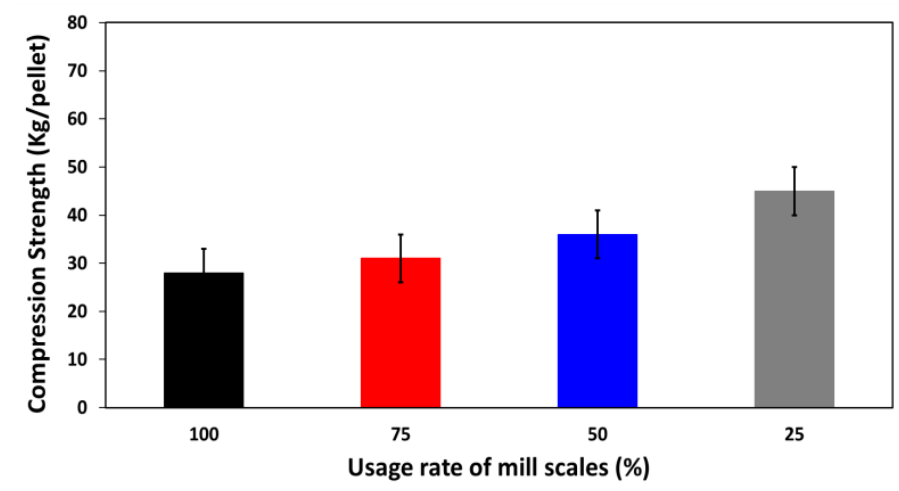

Figure 3. The compression strength of dried pellets. ( $\mathrm{kg} / \mathrm{pellet})$.

Negative affection of wettability causes to decrease in compression strength. In this way, the decrease in the added coke amount has positively affected the compression strength and as the hematite ore has increased in the total blend, compression strength has also shown an increase in parallel to this (Figure 3 ). The results attained from the drop and compression tests were conducted to determine the strengths of the pellets support each other.

\section{B. REDUCTIBILITY}

The reduction degree graph belonging to the pellets reduced for 30 minutes at three different temperatures is given in Figure 4. When the graph is examined, it is seen that the reduction degree increases together with the increasing temperature. When the results attained at $1200^{\circ} \mathrm{C}$ and the results attained at $1300{ }^{\circ} \mathrm{C}$ are compared; while an increase has been observed in the reduction degrees up to $20 \%$ in a way that it will be valid in all blends, increases in very low ratios have been recorded in the reduction degrees when the temperature has increased to $1400{ }^{\circ} \mathrm{C}$. The increasing mill scale ratio has been seen to have positively affected the reductibility and the highest reduction degree has been reached with the blend containing $100 \%$ mill scale. The increase in the added hematite ore has been seen to have caused to decreases in the reduction degree. As seen from XRF (Table 1a) analyses; this situation is foreseen to have been caused by $\mathrm{SiO}_{2}$ content by the ratio of $12,62 \%$ in the ore. The fayalite layer that may stem from Dogantepe gang minerals has been detected to have prevented reduction [1]. Such that; 
it is considered that the occurring fayalite $\left(\mathrm{FeSiO}_{4}\right)$ phase covers the iron oxide surface and slows down reduction [16-17].

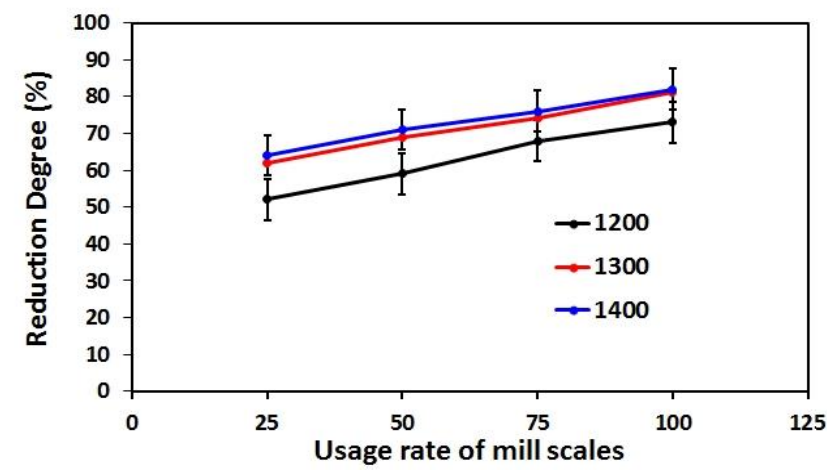

Figure 4. Reduction degree of pellets at different temperatures.

XRD graphs also support the reduction results. When XRD graphs in Figure 5a are considered, it is seen that the oxide iron minerals observed in blend no. 1 before reduction become free after reduction at 1200 and $1400{ }^{\circ} \mathrm{C}$.

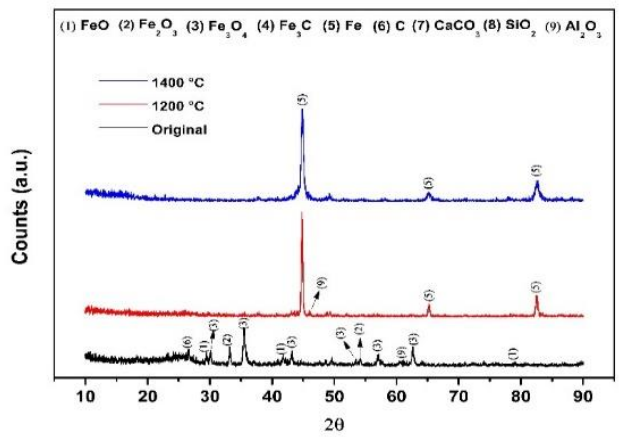

(a)

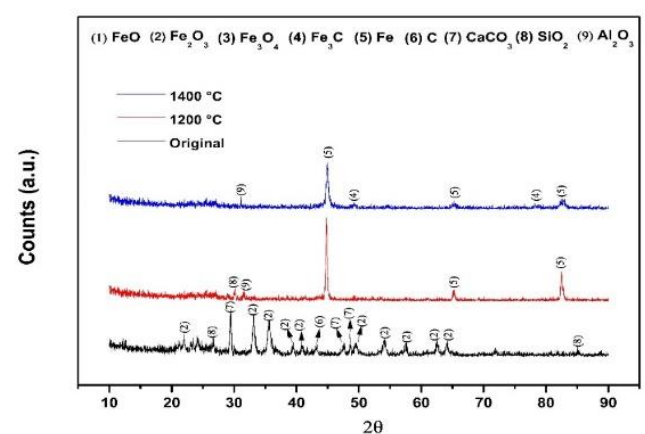

(b)

Figure 5. XRD analysis of (a) S1 and (b) S4 before and after the reduction tests.

When Figure 5b is considered; XRD analyses of the blend no. 4 conducted before the reduction and after the application of the reduction process at the temperature of $1200-1400^{\circ} \mathrm{C}$ temperature are seen. It is seen that reduction has been ensured again in great ratios in iron minerals at $1200{ }^{\circ} \mathrm{C}$, but alumina silicate structures have also been observed in the composition. $\mathrm{SiO}_{2}$ content has not been observed at $1400{ }^{\circ} \mathrm{C}$, but it has been proven that $\mathrm{Al}_{2} \mathrm{O}_{3}$ structures still protect their existence.

The macro photos taken after reduction and the conducted SEM and EDX analyses are given in Figure 6. 


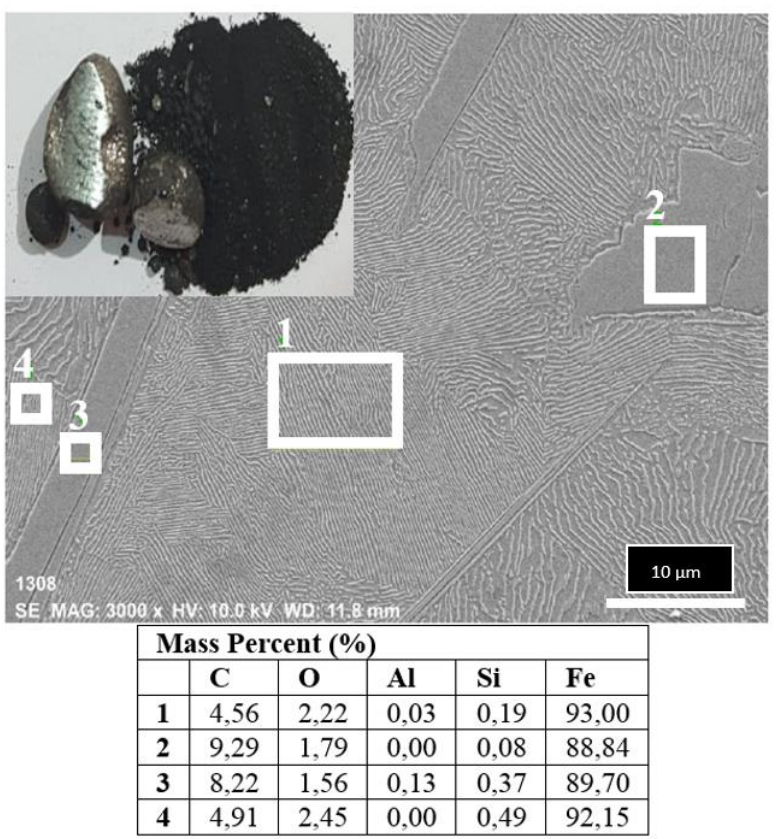

(a)

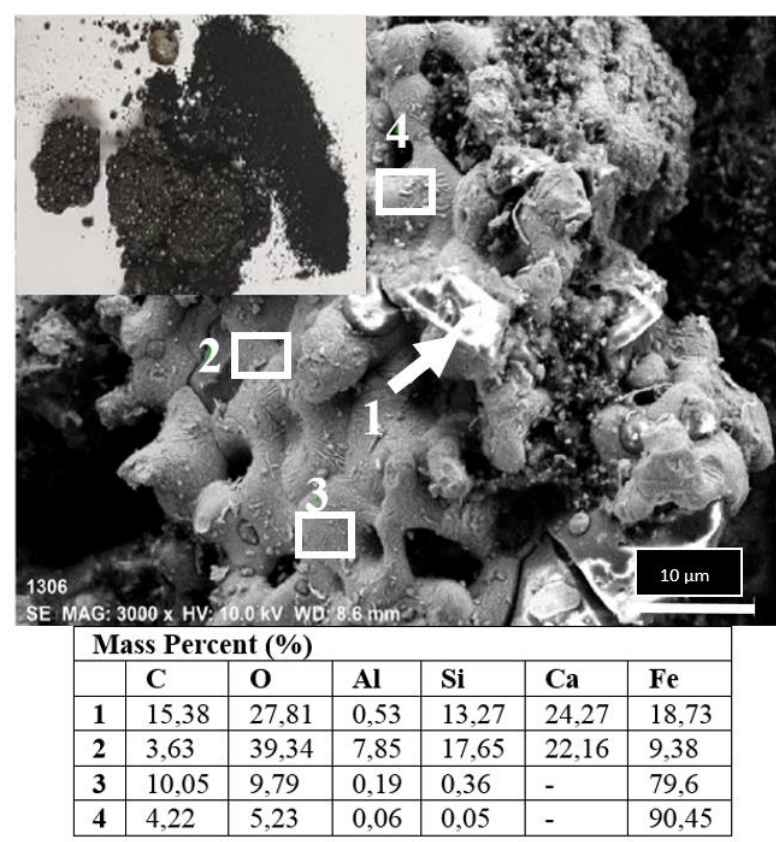

(b)

Figure 6. SEM and EDX analysis of (a)S1 (b)S4 samples after reduction.

As seen from the macro photos; it has been seen that the iron grain production has been completely realized in the sample with S1 code and the slag and metal separation has been completely resulted in. It has been determined that the microstructure of the sample no. S1 has been dominated by iron at high ratios and this result has been supported with EDX analyses. SEM analyses conducted on this sample have shown that a structure similar to that of pig iron has been attained. It has been seen in the examinations conducted on the sample no. S4 that complete reduction has not been ensured. It has been detected in the conducted EDX analyses that there are some slag residues in some parts of the structure. Although the formation of small iron grains has been provided in both macro photos and SEM analyses, the metal-slag separation could not be completed despite the reduction temperature of $1400{ }^{\circ} \mathrm{C}$.

Finally, in the conducted mapping analyses; while $\mathrm{Fe}$ is dominant at a great ratio in the sample with S1 code, $\mathrm{Si}$ and $\mathrm{O}$ are dominant in the sample with $\mathrm{S} 4$ code. This result supports our hypothesis at the beginning and it has shown that the production of iron grain is more efficient without making any blend with any ore from mill scale (Figure 7). 

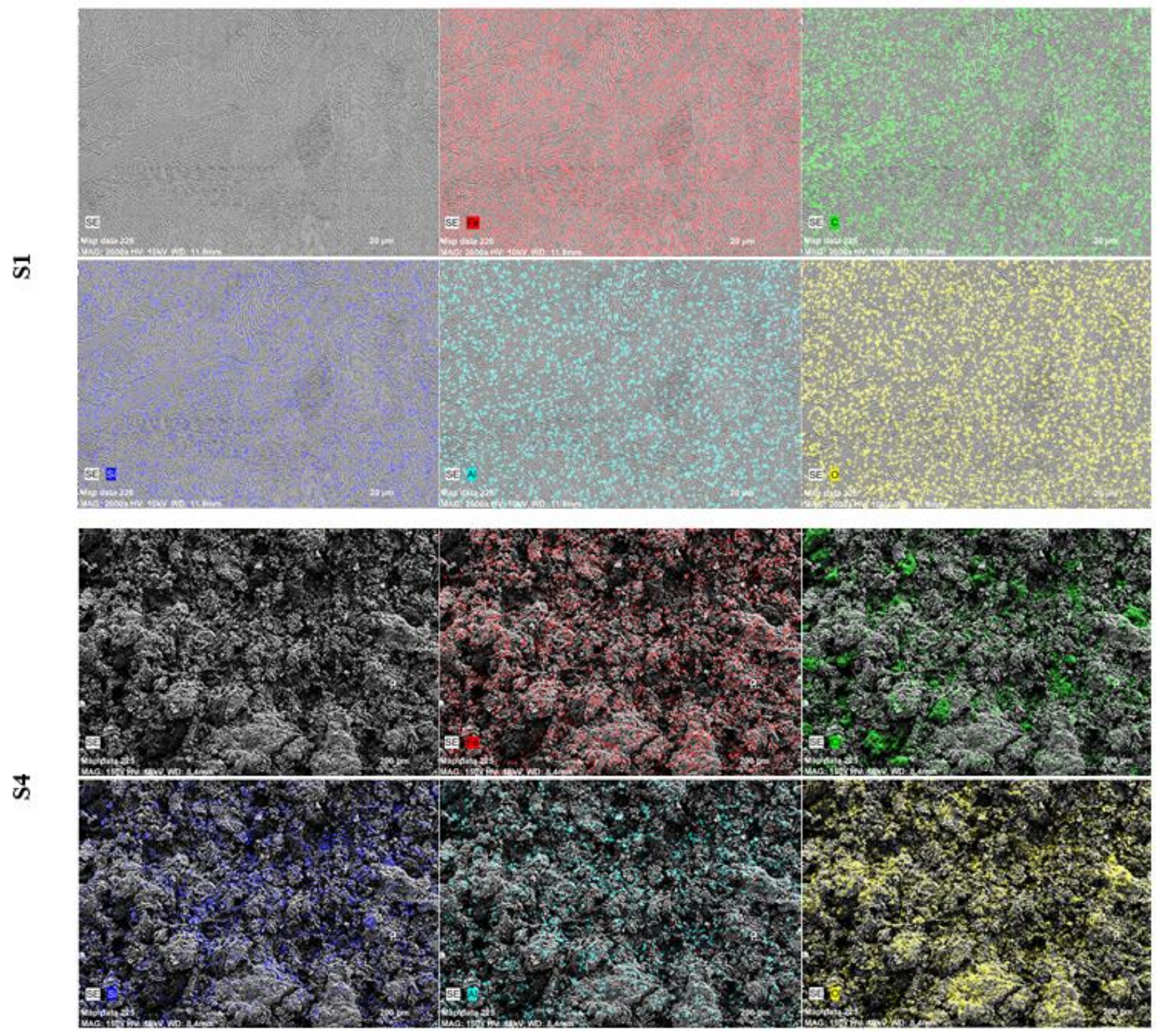

Figure 7. Mapping analysis of pellets after reduction tests.

\section{CONCLUSION}

In this study, pellets from blends containing mill scale at 4 different ratios (100-75-50-25\%) have been successfully produced. While the highest compression strength has been attained from the pellets produced from the blend with S4 code containing $25 \%$ mill scale, the minimum compression strength specified in the literature has been provided in the pellets produced from all blends. While the reduction tests have shown that the hematite ore added to the mill scale negatively affects the reduction, the highest reduction degree has been observed in the pellets with $\mathrm{S} 1$ code containing $100 \%$ mill scale.

ACKNOWLEDGMENT: This research was financially supported by the Scientific Research Projects Coordination Unit of Karabük University grant no. KBUBAP-17-YL-270. 


\section{V.REFERENCES}

[1] G. Doğantepe, "Investigation of hematite iron ores and blast furnace dusts's availability in the sponge iron production," Master thesis, Institute of Science, Karabuk University, Karabuk, Turkey, 2013.

[2] L. Yi, Z. Huang, T. Jiang, R. Zhong, and Z. Liang, "Iron ore pellet disintegration mechanism in simulated shaft furnace conditions," Powder Technol., vol. 317, pp. 89-94, 2017.

[3] E. Cevik, H. Ahlatci, and Y.Sun "Characterization and reduction behavior of cold-bonded composite pellets for direct reduction using an organic binder," Metallurgist, vol. 57, no 5-6, pp. 468477, 2013.

[4] S. Devasahayam, "A novel iron ore pelletization for increased strength under ambient conditions," Sustainable Materials and Technologies, vol. 17, pp. 1-7, 2018.

[5] H. M. Ahmed, N. Viswanathan, and B. Bjorkman, "Composite pellets- A potential raw material for iron making," Steel Research Int., vol. 85, no 3, pp. 293-306,2014.

[6] C. Rubach, "World steel recycling in figures 2006 - 2010 steel scrap - a raw material for steelmaking," Bureau of International Recycling, pp. 1-20, 2011.

[7] T.. C. Eisele and S. K., Kawatra, "A review of binders in iron ore pelletization," Mineral Processing \& Extractive Metallurgy Review, vol. 24, no 1, pp. 1-89, 2010.

[8] I. Kaboyashi, Y. Tanigaki, and A. Uragami, "A new process to produce iron directly from fine ore and coal," Ironmaking Conference Proceedings, Osaka, Japan, 2001, pp.649-657.

[9] I. F. Kurunov, "The direct production of iron and alternatives to the blast furnace in iron metallurgy for the 21 st century" Metallurgist, vol. 54, no 5-6, pp. 335-342, 2010.

[10] K. S. Singh and T. Krishnan, "Reduction kinetics of iron ore pellets and the effect of binders," Master thesis, Department of Metallurgical and Materials Engineering National Institute of Technology, Rourkela, India, 2008.

[11] R. Robinson, "High temperature properties of by-product cold bonded pellets containing blast furnace flue dust," Thermochimica Acta, vol. 432, no 1, pp. 112-123, 2005.

[12] B. Anameric and S. K. Kawatra, "The microstructure of the pig iron nuggets", ISIJ International, vol. 47, no 1, pp. 53-61, 2007.

[13] B. Birol, "The production of composite pellets and iron nuggets from Divrigi pellet concentrate" Master Thesis, Institute of Science, Y1ldız Technical University, İstanbul, Turkey, 2007.

[14] G. Önkibar, "Pig iron production by direct reduction method from integrated iron and steel plant's mill scales," Master thesis, Institute of Science, Sakarya University, Sakarya, Turkey, 2006.

[15] B. B. Agrawal, K. K. Prasad, S. B. Sarkar, and H. S. Ray, "Cold bonded ore-coal composite pellets for sponge ironmaking Part 1 Laboratory scale development," Ironmaking Steelmaking, vol. 27 no 6, pp. 421-425, 2000.

[16] R. Robinson, "High temperature properties of iron and steel making by-product cold bonded pellets," Nordic Recycling Day, Mimer Ciru Centre, Sweden, 2005, pp. 1-15. 
[17] E. Mousa, D. Senk, and A. Babich, "Reduction of pellets-nut coke mixture under simulating blast furnace conditions,” Steel Research Int., vol. 81, no 9, pp. 706-715, 2010. 